\title{
A KELETI-KÁRPÁTOK ISZAPVULKÁNJAI
}

\author{
MUD VOLCANOES OF THE EASTERN CARPATHIAN MOUNTAINS
}

\author{
MÓGA JÁNOS \\ ELTE TTK FFI Természetföldrajzi Tanszék \\ jmoga@freemail.hu
}

\begin{abstract}
This study presents the examination results of the landform development of a mud volcano area located in the Buzău Geopark, which is lying along the outer rim of the Eastern Carpathian Mountains. Between the settlements of Berca - that lies in the valley of River Buzău - and Beciu - approximately $30 \mathrm{~km}$ further to the north - mud volcanoes appear linking to the axis of a north-south anticline. In the axis of the anticline and along the fault zone that crosses the axis the mud with saline oily water flows upward to the surface due to the pressure of methane gas. In the area of the anticline zone, next to the well-known Pâclele Mari and Pâclele Mici mud volcanoes, there are two other mud volcano areas named Fierbători (its meaning 'where the water is bubbling') in the south, at the border of Berca, and the less known Beciu in the northern part of the zone.
\end{abstract}

Keywords: mud volcano, Buzău Geopark, landforms, gryphons, mudpools, mudlobes

\section{Bevezetés}

A Kárpátokban nincsenek már működő tüzhányók, de ha valaki a vulkáni müködés jelenségeit szeretné tanulmányozni, nem kell feltétlenül távolabbi tájakra utaznia, valami hasonlót lehet látni, megtapasztalni kicsiben a Keleti-Kárpátok iszapvulkáni területein (1. ábra), ahol mintha az igazi vulkánok kisebb méretü modelljét látnánk, a vulkáni működés és felszínformák számos analógiájával találkozhatunk ezeknél a jelenleg is működő „hideg vulkánoknál”. A mélyebb rétegekből felszínre törő gázok hígan folyós sarat, sáros, sós, olajos vizet, iszapot préselnek ki a kürtőkön keresztül, amiből akár 10-15 m magas, kráterrel koronázott „vulkáni” kúpok épülnek. Megcsodálhatjuk a kráterekben, iszapmedencékben állandóan bugyogó sártavakat és a belölük kifolyó sárfolyásokat, amelyek kísértetiesen hasonlítanak a valódi vulkáni területek lávafolyásaihoz, noha semmi közük nincs a magmatikus folyamatokhoz.

Tanulmányunkban a Keleti-Kárpátok külső szegélyén a Bodza-folyó mentén kialakított Buzău Geopark területén található iszapvulkánok müködési folyamatait és jellegzetes formakincsét ismertetjük. Az említett geopark gazdag földtani és morfológiai értékekben, számos geotóp, azaz földtudományi értéket hordozó helyszín, objektum 
található a területén, amelyek között a flis és molasz öv jellegzetes üledékföldtani és tektonikai jelenségei, sódiapírok, gázszivárgási helyeken kialakult öröktűz, különleges homokkő sziklaalakzatok és sókarsztos felszínformák mellett az iszapvulkánok jelentik a legérdekesebb látnivalókat (ANDR ǍșANU, A. 2010). Ezért a geopark nemcsak a földtudományokkal foglalkozó kutatóknak, hanem földrajztanároknak és diákoknak is érdekes úti cél. A sárvulkánok környékén különböző igényeket kielégítő szállások találhatók, amelyek az Interneten is elérhetők. A Pâclele Mici melletti táborozóhelyen sátorban is meg lehet szállni, onnan kiindulva egy-két nap alatt bejárhatók a közeli iszapvulkáni területek, a Pâclele Mare iszapvulkáni területen kialakított rövid tanösvény pedig szakszerü eligazítást nyújt az érdeklődőknek. A geopark egyéb látnivalóival kiegészítve több napos tanulmányútra nyílik lehetőség a Kárpátok ezen a kevéssé ismert, de földtani-felszínalaktani értékekben nagyon gazdag részén.

\section{Hol keletkeznek iszapvulkánok?}

Az iszapvulkánok a Kárpátok tektonikailag egyik legaktívabb területén, a Vrancea-zóna közelében találhatók és kialakulásukban ugyanazon tényezők játszottak szerepet, mint az Eurázsiai-hegységrendszer egyéb iszapvulkáni területein: szénhidrogén- (kőolaj- és földgáz-) csapdák találhatók a területen, és aktív szerkezeti mozgások meghatározók, amelyek az agyagos és gyakran sótartalmú üledékekből álló rétegsorokból felboltozódásokat, gyűrt szerkezeteket és sótömzsöket (sódiapírokat) alakítanak ki. A metángázt tartalmazó szerkezetekben túlnyomásos övek jöttek létre (Diмıтrov, L. I. 2002, Mazzini, A. - ETiope, G. 2017), amelyek elősegítették az iszapvulkánok képződését. Az iszapvulkánok a Keleti-Kárpátok déli részén (Szubkárpátok) a Belső-elötérsüllyedéknek (Inner Foredeep) nevezett geológiai szerkezet területén jelennek meg, ahol régóta olaj- és gázkitermelés folyik, és gyakoriak a sódiapírok is. A Bodza-folyó völgyében fekvő Berca és a tőle kb. 30 km-re észak felé eső Beciu települések között a sárvulkánok egy É-D-i irányú antiklinális tengelyéhez kapcsolódva jelentkeznek (1. ábra). A Berca-Arbănaşi antiklinális tengelyében és az azt harántoló vetőzóna mentén (2. ábra) áramlik fel a sár - sós, olajos vizekkel együtt - a metángáz nyomása következtében a felszín felé (SтогсA, M. et al. 2017). A Buzau Geopark területén, az antiklinális zóna középső részén a jól ismert Pâclele Mari és Pâclele Mici (a régi topográfiai térképeken Puklának nevezik ezeket) sárvulkánok mellett a környéken még két másik iszapvulkáni terület található: délen Berca határában a Fierbători (jelentése: „ahol bugyog a víz”), valamint a zóna északi részén a kevésbé ismert Beciu iszapvulkáni terület. 


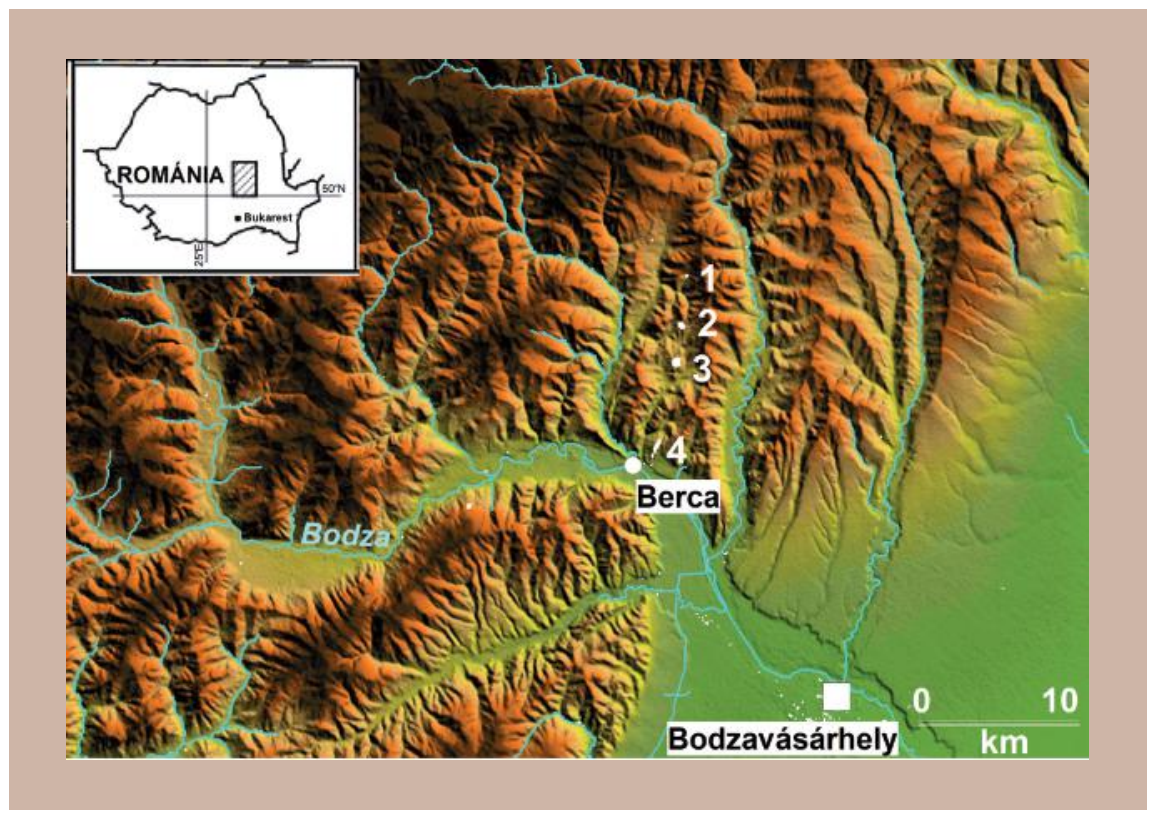

1. ábra. A Berca és Beciu közötti iszapvulkáni területek a Buzau Geopark területén (SRTM Worldwide Elevation Data, 3-arc-second Resolution alapján Global Mapper 18 programmal szerk. Móga J.) Jelmagyarázat: 1 = Beciu terület, $2=$ Pâclele Mari terület, $3=$ Pâclele Mici terület, $4=$ Fierbători terület

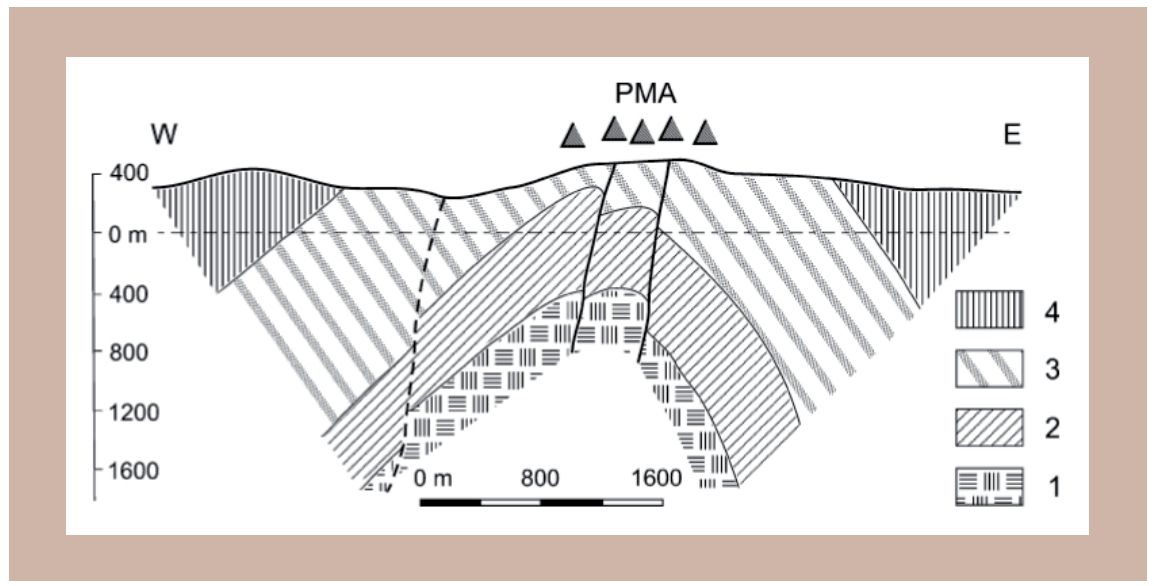

2. ábra. A Berca-Arbănaşi antiklinális földtani szelvénye a Pâclele Mari iszapvulkáni területén (PMA) keresztül (Ciocârdel, R. 1949 nyomán szerk. Móga J.) Jelmagyarázat: 1 = márgába ágyazott sóbreccsa (középsö-miocén), 2 = olajat tározó homok és homokkő rétegek (felsö-miocén), 3 = homokkö, agyagpala (felsö-miocén), 4 = márga, homok, agyagpala váltakozása (pliocén) 
Az iszapvulkánok a Föld viszonylag ritka jelenségei közé tartoznak, főként a lemezhatárokhoz (konvergens lemezszegélyekhez) kötödve hegységképződési zónákban alakulnak ki (Higgins, G. E. - SAunders, J. B. 1974, Dimitrov, L. I. 2002, Kopf, A. J. 2002). A szárazföldi iszapvulkánok közel egynegyed része összefügg az AlpokKárpátok-Himalája övvel. Ismert előfordulási helyek vannak Észak-Olaszországban Bologna környékén és Szicíliában Agrigento környékén, továbbá Ukrajnában és Oroszországban a Fekete-és Azovi-tenger menti területeken, valamint Azerbajdzsán és Pakisztán területén (Dimitrov, L. I. 2002). Romániában a Szubkárpátok területén kialakult iszapvulkánok régóta ismertek (CoBĂLCescu, G. 1883, CiocÂrdel, R. 1949). Az erdélyi iszapvulkánokról BÁNYAI J. (1932) készített tanulmányt, míg az utóbbi években GÁL A. (2010) tanulmányozta és rendszerezte a formákat, iszapmedencéket, iszapos kúpokat, iszapkupolákat és iszapos kalderákat talált a vizsgált területeken. A KeletiKárpátok külső szegélyén, a Berca-Arbănaşi antiklinálison sorakozó iszapvulkánok a leglátványosabbak és legaktívabbak (CiocÂrdel, R. 1949, BRustur, T. et al. 2015, Melinte-Dobrinescu, M. C. et al. 2017). A feltörő gázok mennyiségét és összetételét vizsgálva megállapították, hogy a gáz több mint 95\%-ban metánt $\left(\mathrm{CH}_{4}\right)$ és kb. 3\%-ban $\mathrm{CO}_{2}$-t tartalmaz. A Pâclele Mari és a Pâclele Mici telephelyekröl származó iszapvulkánok metánkibocsátását 730 tonna/év, illetve 383 tonna/év mennyiségünek becsülték (Етіоре, G. et al. 2009). Napjainkban, amikor az üvegházgázok éghajlat-módosító káros hatásait vizsgálják, ezeket is figyelembe kell venni (Dimitrov, L. I. 2002).

\section{Az iszapvulkáni terület felszínformái}

A redőteknő tetején kialakult iszapvulkánok négy nagyobb csoportban emelkednek a Bodza folyó menti területen. A két legjelentősebb, geoturisztikai szempontból is legérdekesebb, a látogatók számára megnyitott iszapvulkáncsoport az 1924-ben kijelölt geológiai és botanikai rezervátum területéhez tartozó Pâclele Mari és Pâclele Mici. A Pâclele Mari terület a közepét uraló nagyméretű iszapvulkánjáról - átméröje meghaladja a 100 m-t - kapta a nevét A fö kúpot kisebb kúpok és parazitakráterek veszik körül, amelyekből a bőségesen kiömlő sár minden irányban legyezőszerűen szétterülő iszapnyelveket képez (3. ábra). A fennsík jellegű Pâclele Mici 9,4 ha-nyi kiterjedésű természetes rezervátum 1924 óta, ahol a földtani-felszínalaktani értékek mellett a különleges sótürő (halofita) növényzet is védett. A Pâclele Mici területen a sárvulkáni kúpok nagyobb számban jelennek meg, nagyon változatos morfológiai arculattal. A legtöbb és legmagasabb rétegvulkáni szerkezetek itt emelkednek, kb. 10 m magasak; kráterek, iszapmedencék, sárfolyások, és az iszap folyásához és száradásához kapcsolódó mikroformák teszik különösen érdekessé (4. ábra). 


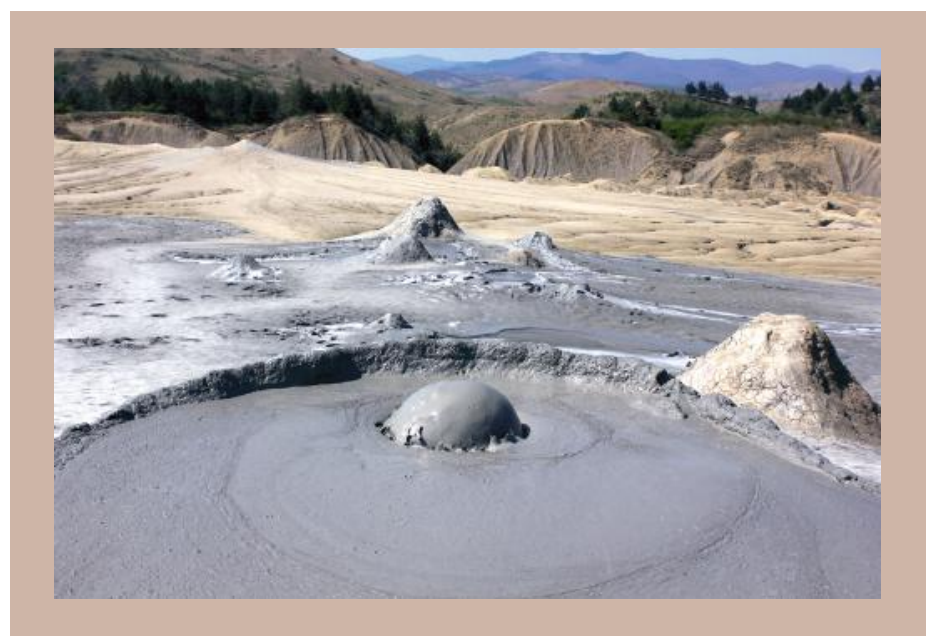

3. ábra. A Pâclele Mari iszapvulkáni terület közepét uraló nagyméretü iszapvulkán (fotó: Móga J.)

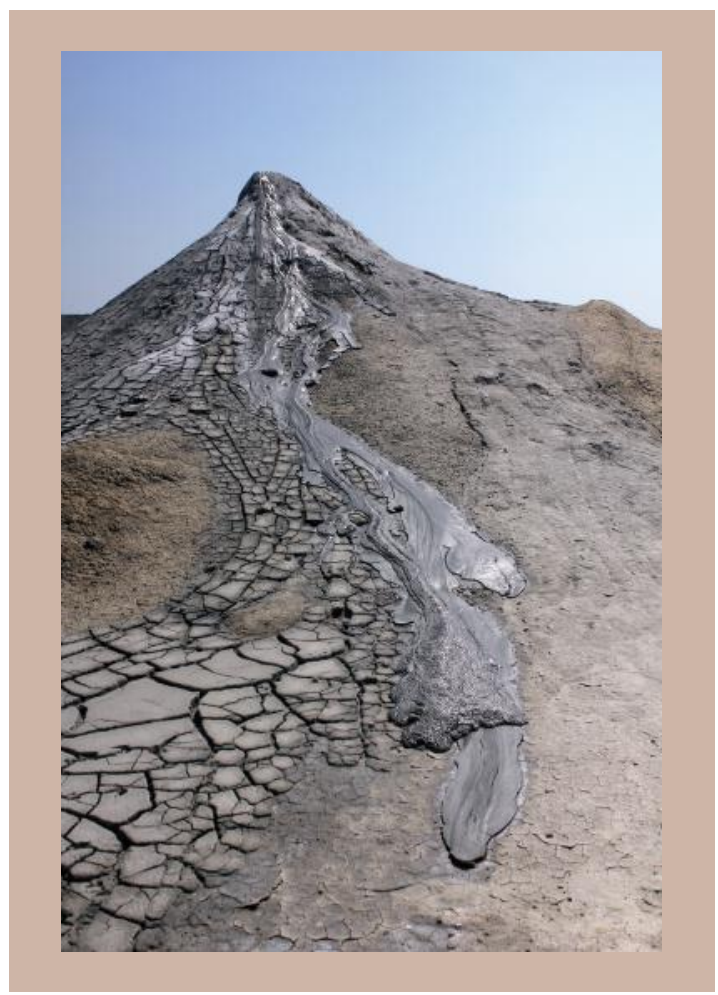

4. ábra. A Pâclele Mici iszapvulkáni területen a vulkáni kúpok nagyobb számban jelennek meg és magasabbak, mint a többi területen (fotó: Móga J.) 
A Bodza folyóhoz közeli tetőkön termelő olaj- és gázkutak között egy kiterjedt badland vidék közepén bújik meg a Fierbători iszapvulkáni terület, ahol „bugyog a víz”. A bugyogás nem a forráspont miatt alakul ki az ott található iszappal, olajos, sós vízzel kitöltött medencékben, hanem a gázbuborékok folyamatos felszínre áramlása tartja mozgásban a vizet. Valószínủleg nem egy felszín alatti tározóból táplálkoznak, mivel a sűrű, sötét, viszkózus sárral kitöltött medencék hígan folyós sárral, olajos vízzel teli kráterekkel váltakoznak kis távolságon belül is.

A Beciu terület a Berca-Arbănaşi antiklinális négy ismert iszapvulkáni előfordulási helye közül a legkisebb méretü. Lapos, dóm alakú, dél felé lejtősödő ovális térszín, ahol mintegy 200x100 m átmérőjű területen szétszórtan gryphonok (sárkúpok) és iszapmedencék jelennek meg magányosan vagy kisebb csoportokban (5., 6. ábra). A kis- és mikroformák azt sejtetik, hogy ez a legfiatalabb a négy iszapvulkáni terület közül.

\section{Az iszapvulkánok formakincse}

Az iszapvulkánokat müködésük szerint a valódi vulkánokhoz hasonló csoportokba sorolhatók, működő, alvó (szunnyadó) és kihunyt (inaktív) iszapvulkánokat egyaránt

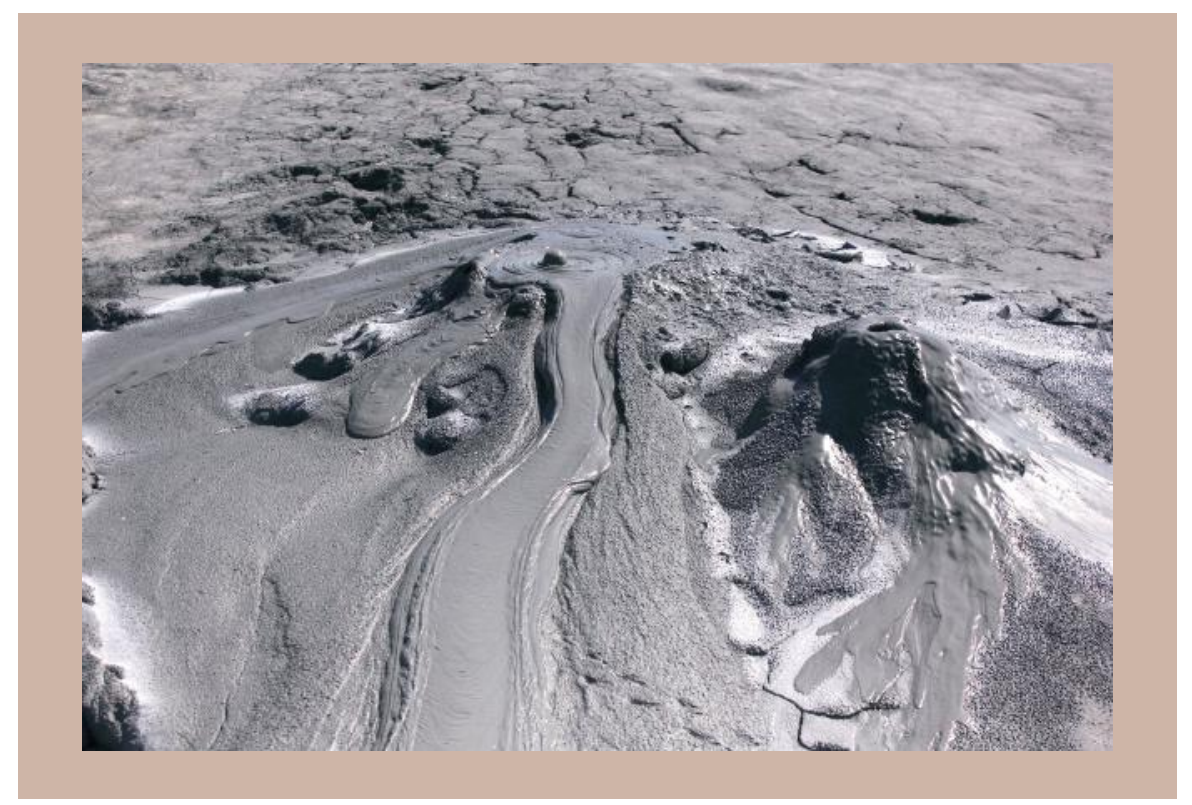

5. ábra. A sárkúpok (gryphonok) magányosan vagy kisebb csoportokban emelkednek (fotó: Móga J.) 


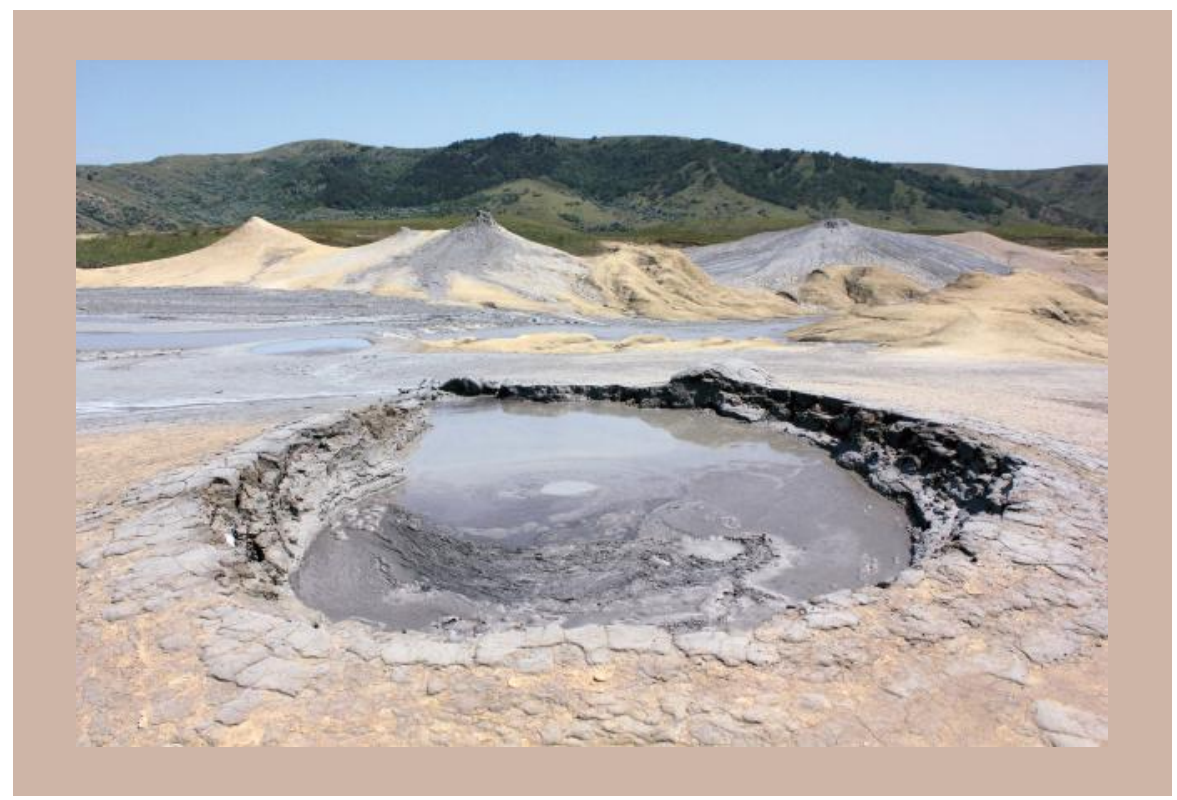

6. ábra. Elszórt megjelenésü sárkúpok (gryphonok) és iszapmedencék a Pâclele Mici területen (fotó: Móga J.)

láthatunk a vizsgált területeken (Mazzinı, A. - ETiope, G. 2017). Legnagyobb és legszembetűnőbb formái a felszínre emelkedő sár- vagy iszaprétegek lerakódásaiból kialakult iszapvulkáni kúpok (gryphonok). A kúpok lejtőinek meredeksége a szemcsemérettől és a kitört anyag sürűségétől függ, de lejtőszögük általában eléri a $45^{\circ}$-ot. A sárkúpok átlagos magassága 3-4 m, a legmagasabbak a Pâclele Mici területen vannak, ahol magasságuk elérheti a 10 m-t is. Ezek a szabályos kúpok (rétegvulkáni szerkezetek) rendszerint az iszapvulkáni terület központi részében csoportosan jelennek meg vagy a tektonikai vonalak által meghatározott rendben sorakoznak. A legtöbb kúp tetején kráter nyílik, amelyben bugyborékoló sártó található. Az iszapvulkánok nagy része a buborékoló típusú gryphonok csoportjába tartozik, ahol a sárral kitöltött kráterekben folyamatosan képződnek gázbuborékok. A buborékoló gryphonok alatt néhány száz vagy akár ezer m mélyen általában egy sárkamra található, ami egy keskeny csatornán keresztül folytonos sár-, víz- és gázutánpótlást nyújt a sárral teli kráternek, így abban folyamatos a buborékolás. Miután a kráterben lévő medence megtelik, az iszap rendszeresen túlfolyik, és egy vagy több irányba kifolyva sugarasan szétterül a kúp körül. A kráterek a meredek lejtőkkel határolt kúpok tetején kisebbek, néhány dm átmérőjűek, a lapos dóm alakú kitörési központok tetején elérhetik a 3-4 m-es átmérőt. A legnagyobb 
iszapkráter a Pâclele Mare fö kitörési központja, ahonnan bőségesen árad ki a híg sár, egy kb. 100 m átmérőjü dómot kialakítva maga körül müködése során (3. ábra). A négy vulkáni területen néhány iszapvulkán furcsa köpködő müködésével hívja fel magára a figyelmet, ezek a fröcskölö típusú gryphonok csoportjába tartoznak. A sárfröcscsök egy keskeny kürtőből időszakosan fröccsennek ki (7. ábra), amit a felszín alatti sárkamrában felhalmozódott gázok túlnyomása okoz. A fröcskölő gryphon krátere alatt a kürtő általában egy olyan sárkamrához csatlakozik, ahol változik a gáznyomás, aminek a növekedése időnként lehetővé teszi az iszap periodikus felhajtását a felszín felé (Mazzini, A. - Etiope, G. 2017).

Az iszap víztartalma változó, emiatt a viszkozitása is különböző. A száraz és forró időszakokban, amikor a folyadékok szivárgása magas párolgással társul, a gryphon tetejére vezető kürtő felső részében a sár kiszáradhat és cementálódhat. Ilyenkor szünetel a müködés. A hosszúra nyúlt szünet, vagy akár az időjárási jelenségek - például ha az eső által okozott eróziós letarolás meghaladja az iszaplerakódás mennyiségét - hatására a gryphon elpusztulhat. Csak a folyamatosan müködő gryphonok tartják meg eredeti alakjukat. Mivel a gázok feláramlási helye változhat, a kitörési központok müködése is változik. Ha valahol elzárul a kürtő, a gázok más helyet találnak maguknak és máshol fog

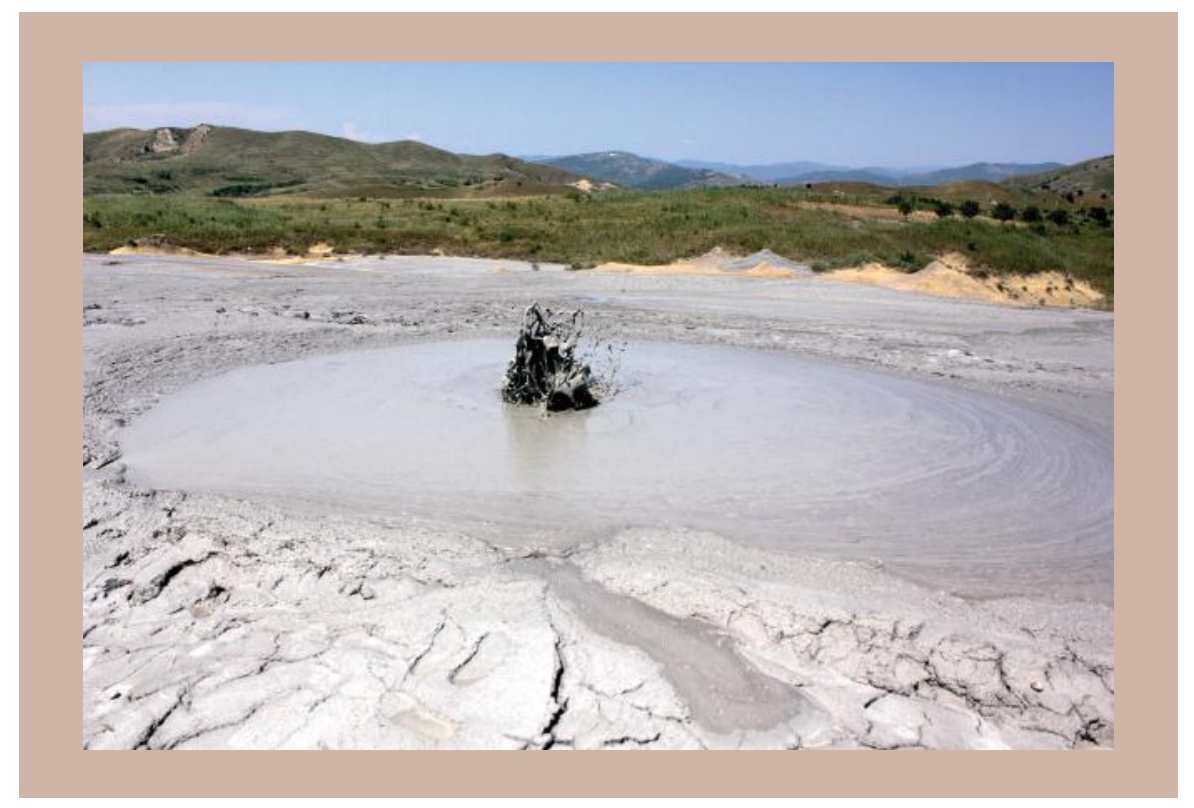

7. ábra. Fröcskölö sárkúp (gryphon) (fotó: Móga J.) 
az iszapvulkáni tevékenység felerősödni. Vannak nagy számban alvó, szunnyadó kúpok is, amelyeknek még ép a krátere, és akadnak olyanok is, ahol az erózió már elpusztította azokat. Az utóbbi öt évben végzett folyamatos vizsgálataink során érzékeltük az iszapvulkánok aktivitásának a változásait, az alvó kráterek ébredését is.

Az iszapvulkáni tevékenység másik szembetünő helyszínei az iszapmedencék. A medencék körkörös bugyborékoló felszínek, többnyire alacsony peremük van (8. ábra), de léteznek perem nélküli medencék is. A medencék átmérője néhány centimétertől néhány méterig, mélységük néhány $\mathrm{cm}$ és néhány $\mathrm{m}$ között változik. Ezeken a helyeken a víz - esetenként sós olajos víz - folyamatosan áramlik a felszínre gázzal és kisebb mennyiségü finom szemcséjü üledékekkel együtt. Az egymás mellett nyíló medencékben különbözik a fluidok összetétele és nagyon eltérö lehet pl. az olajtartalmuk, ami különálló felszín alatti tápláló kamrákra és csatornarendszerre utal. A bugyogások módja és helyzete alapján centrális és diffúz táplálású iszapmedencék különböztethetők meg. A centrális táplálású iszapmedencék az iszapfelszínbe bemélyülő körkörös vagy ellipszishez hasonlóan megnyúlt kis medencék, amelyeket olajos víz, hígan folyós vagy viszkózus sár tölti ki. Közös tulajdonságuk, hogy egy konkrét helyen törnek fel a gázok nyomására a folyékony és gáznemü anyagok. A feltörő anyag mennyiségétől és

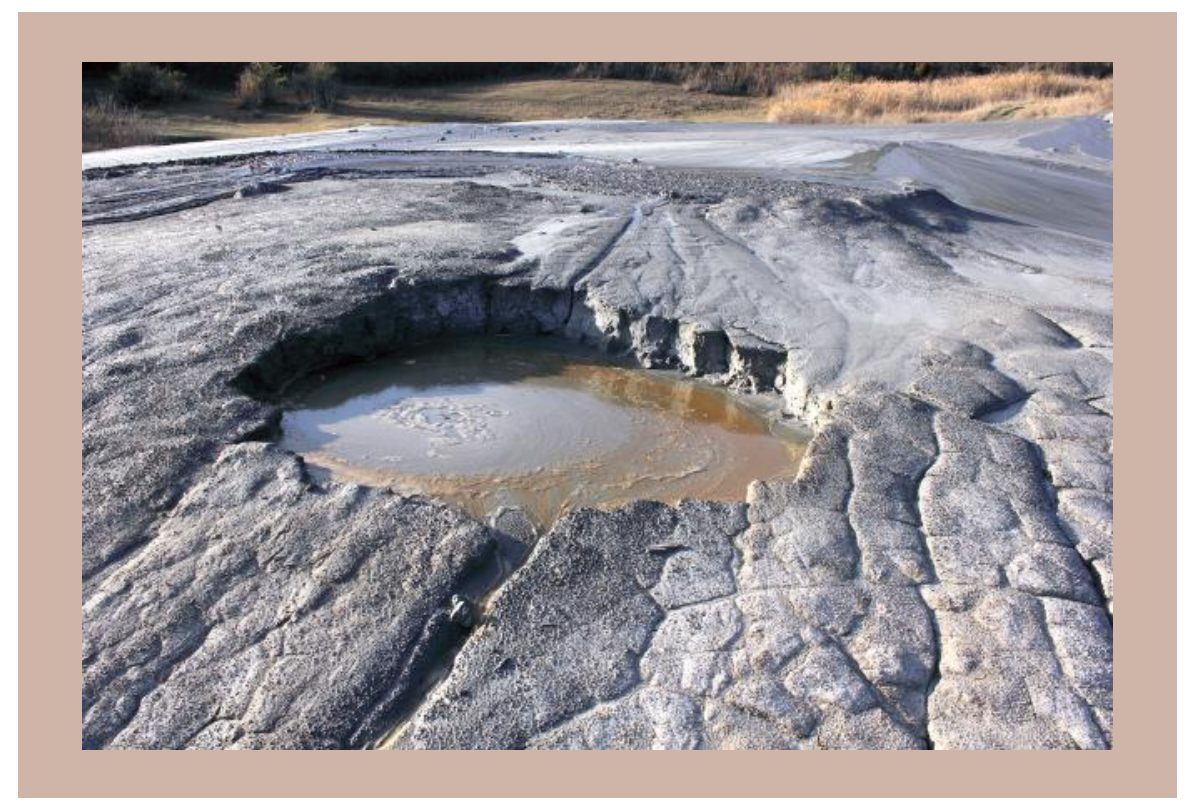

8. ábra. Iszapmedence (fotó: Móga J.) 
minőségétől függően lehetnek különbözőek. Ahol csak gázok törnek fel, ott általában lefolyástalanok a mélyedések, legtöbbször azonban a folyékony összetevők egy vagy akár több helyen túlcsordulnak, és akár több tíz m hosszú víz-, illetve hígan folyós vagy viszkózus iszapfolyásokat táplálnak, amelyek legyezőszerüen szétterülnek a lejtős területeken. A diffúz táplálású iszapmedencék az előzö típushoz hasonló kis medencék, a fő különbség közöttük az, hogy ezekben a különböző halmazállapotú anyagok felszínre törése több pontban, gyakran a kis medence belső peremén diffúz módon történik. Néha előfordul, hogy egy kis medencéből több kifolyás indul, amelyek eltérő forrásból származó anyagokat (víz, olaj, sár) szállítanak.

\section{A sárfolyások típusai és mintázata}

Aktív és inaktív sárfolyások egyaránt nagy számban fordulnak elő az iszapvulkáni területeken, mivel az iszapvulkánok szezonális aktivitása, anyaga és a kifolyt sár mennyisége gyakran változik, és ezek befolyásolják a lefolyás típusát és irányát is. Jóllehet a kúpok körül sugarasan széttartó (centrifugális) sárfolyások keletkeznek, de azok aktivitása és a lefolyás iránya szüntelenül változik, másrészt a kráter vagy medence túlfolyó nyílása általában csak egy-két kitüntetett irányba engedi lefolyni a sarat, amelyeknek a helye is módosulhat idővel, ezért az idősebb, kiszáradt sárnyelvek és a friss, aktív sárfolyások keresztezik egymást. A kúpoktól távolabb eső laposabb térszíneken előfordulhat, hogy két különböző kibocsátó helyről származó sárfolyás keresztezi egymás útját, a sűrűbb sárfolyás eltérítheti a másikat a korábbi lefolyási irányból. A medencékből kiinduló fluidok nagyon különbözők anyaguk és viszkozitásuk tekintetében. A leghígabbak hígan folyós olajos vízzel elegyedő, minimális lebegő anyagot tartalmazó fluidok, amelyek kevés nyomot hagynak a felszínen. A híg sárfolyások a nagyobb esésü lejtőkbe bevágódnak, pár cm széles és mély vályút alakítanak ki, amelynek a szélén a lerakódott és megszáradt sár peremet képez. A négy fő iszapvulkáni terület az állandóan egymásra rakódó iszapfolyások miatt dómszerủen emelkedik ki az alacsonyabb környezetéből. Az iszapdomb lejtőin jól megfigyelhetők a különböző forrásokból származó, különböző színű és anyagú sárfolyások. Jól elkülönülnek a friss, valamint az idősebb, kiszáradt, poligonális repedéshálózattal borított sárfolyások. Ritkán kialakulnak sürü viszkózus sárfolyások is, amelyek a pahoehoe lávához hasonló fonatos mintázattal rendelkeznek (9. ábra).

A felszínen lefolyó fluidok eróziós tevékenységét tanúsítják a felszínbe bemélyedő vályús sárfolyások, amelyek lehetnek többé-kevésbé egyenes lefutásúak és meanderezők is. Kialakulhat perem a vályúk szélén, ami főleg a sürübb sárfolyásokra jellemző, 


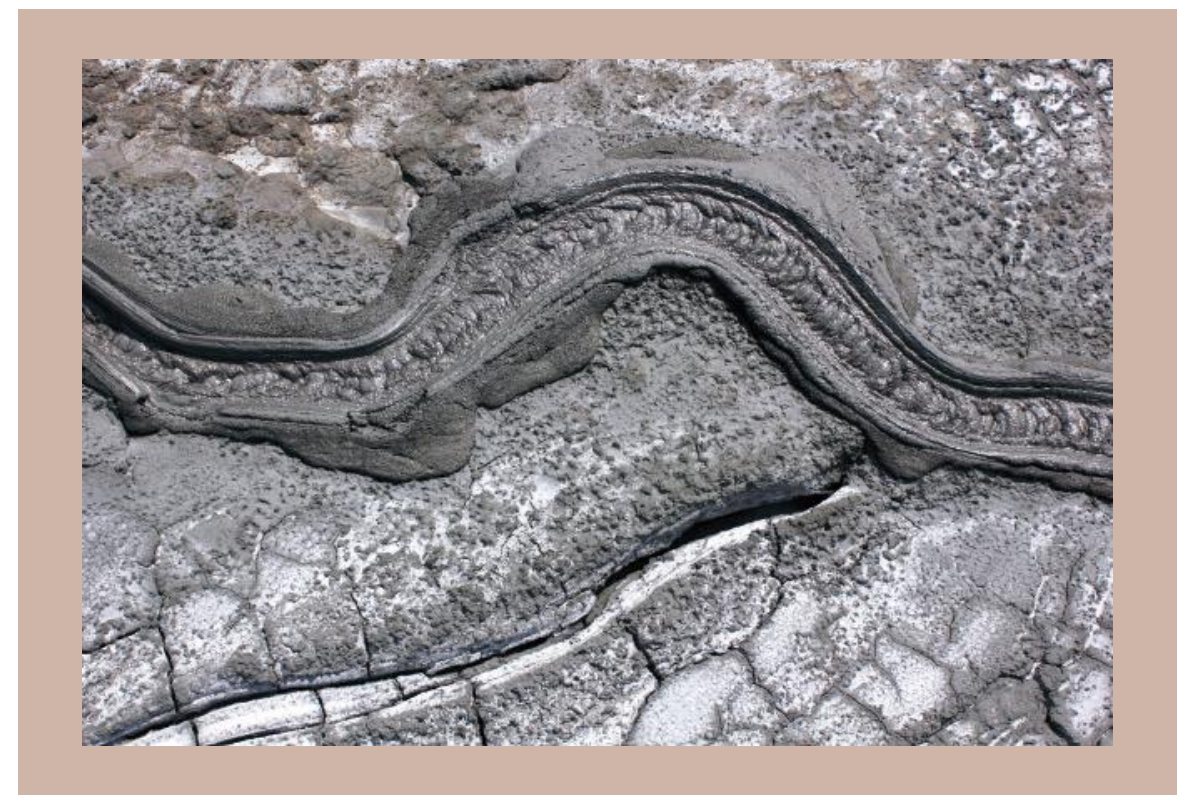

9. ábra. Sürü viszkózus sárfolyás a pahoehoe lávához hasonló fonatos mintázattal (fotó: Móga J.)

de vannak perem nélküliek is. A fluidok, sárfolyások általában határozott mederben kezdik útjukat, bevágódhatnak, a lejtőszög csökkenésével meanderezésbe kezdenek, azután iszapnyelveket alakítanak ki és szétterülnek. Mivel a négy fö iszapvulkáni terület dómszerủen emelkedik ki a környezetéből, így a nagyobb hozamú sárfolyások mély árokrendszereken keresztül érik el a fövölgy talpát. Ezek az akár $10 \mathrm{~m}$ mély centrifugálisan lefutó árkok látványos badlandvidékké formálták az iszapvulkáni területek peremét.

Gyakori a sárfolyások (vályúk) szétválása és egyesülése. Különösen látványos kisformák alakulnak ki, ha különböző típusú (anyagú vagy viszkozitású) sárfolyások keresztezik egymást. Sárhidak és alagutak alakulnak ki ott, ahol a híg sárfolyás tetején a sűrű iszap kérget képez, ill. egy vályút a későbbi sárfolyás keresztez, és úgy képez fedelet a vályú felett, hogy alatta a vályú nyitva marad vagy csak részlegesen zárul el, amit egy későbbi híg sárfolyás újból megnyit. Jól felismerhető a pszeudokarsztos üregesedés két formája az iszapvulkáni terület lejtős peremvidékén. A pszeudokarsztok (álkarsztok) a karszthoz hasonló felszínformákkal rendelkeznek, és a vízelvezetés is föleg felszín alatti csatornákon keresztül történik, de lényegében hiányzik a karsztos oldódás (korrózió) és erózió a rendszer létrejöttének folyamatából. Rheogén pszeudokarsztos - ez eredetileg a lávafolyásokon kialakult karsztszerü formákra, pl. lávakéregbarlangokra alkalmazott 
kifejezés - jelenségek alakultak ki ott, ahol a vályúban lefolyó víz felszínén a sűrűbbé váló anyag redőződik, összeáll és befedi a hígan folyó sárcsatornát. Ezek a mikroméretű fedett alagutak hasonlóképpen képződnek, mint a valódi vulkáni területek lávafolyásainál a lávakéregbarlangok (SzÉKely A. 1974, Halliday, W. R. 1976, 2006, Gadányi P. 2008). A badland területek pszeudokarsztos jelenségeit víznyelők, sárhidak és sáralagutak, valamint kisebb barlangok kialakulása jelzi (10. ábra). Ezek alagosodásos (szuffóziós) folyamatok jelenlétéről tanúskodnak (Otvos, E. G. 1976, PARker, G. G. et al. 1990, Zhu, T. X. et al. 2002, Veress M. 2004).

\section{Egyéb kisformák}

A monogenetikus mini iszapkúpokat (dagadókúpokat) egyszeri viszkózus sárkitörés hozta létre. Szabályos kúp alakú, kráter és kürtő nélküli, $0,2 \mathrm{~m}$-nél kisebb átmérôjü és 0,5 m-nél általában nem magasabb mikroméretü pozitív formák. Valószínűleg a gázok

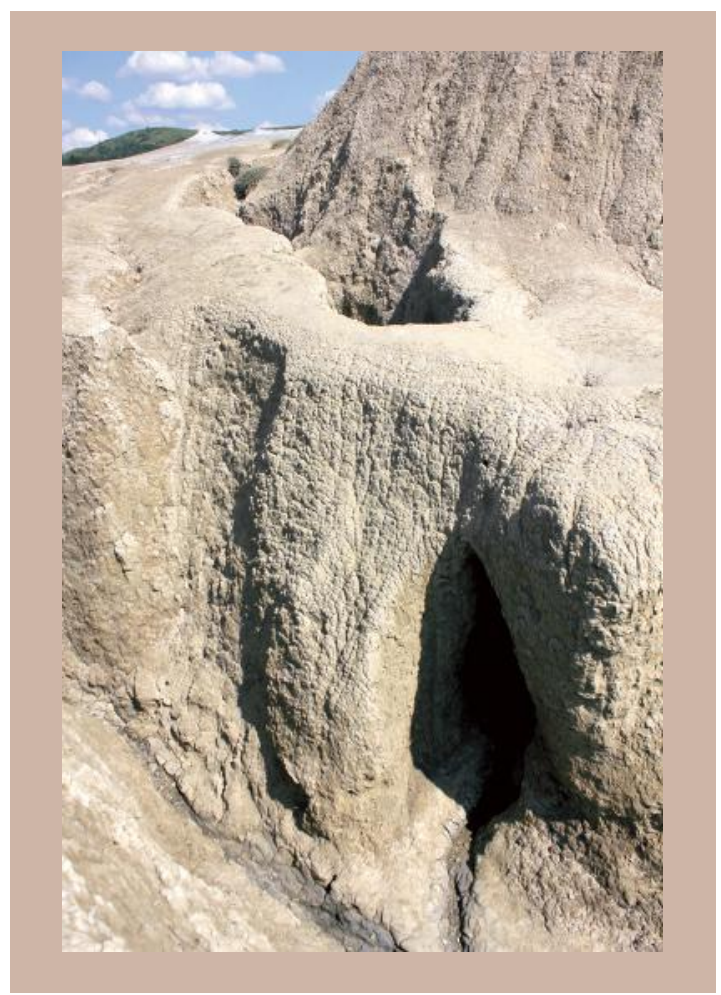

10. ábra. A badland területek pszeudokarsztos jelenségeit víznyelök, sáralagutak, kisebb barlangok képviselik (fotó: Móga J.) 
nagy nyomóereje préselte ki a sürü viszkózus iszapot a kürtőn át, amely helyben megszilárdult és elzárta a kürtő nyílását. Keletkezésük a vulkáni dagadókúpokéhoz hasonló. Főleg a Beciu iszapvulkáni területen fordulnak elő egyéb más mikroformákkal együtt. $\mathrm{Az}$ iszapmaarok 0,1-0,2 m átmérőjü peremmel körülvett, maar jellegü monogenetikus kisformák, kürtő nélkül. Az iszaplyukak 0,1-0,2 m átmérőjü, nyitott perem nélküli lyukak az iszapban. A legtöbb sárlyuk szunnyadó állapotban van, időnként kisebb sárfolyások indulhatnak ki belölük. Az alveolusok parányi gödröcskék az iszapfolyások felszínén, amelyeket a friss iszapfolyásokban megrekedt és onnan távozó gáz alakít ki. Az ilyen láthatatlan gázkibocsátást „mini seepage” néven említik (ETIOPE, G. et al. 2011), eredménye egyfajta gömbölyü miniforma, amely körülveszi a szellőzőnyílást, és sok iszapvulkáni területen előfordul szinte az egész sáros térszínen. Poligonális repedéshálózat is megtalálható, ezek tulajdonképpen száradási nyomok, mint az agyagsivatagoknál (kevír, takir); a kiszáradó sárfolyások felszínén a száradás következtében létrejövő térfogatcsökkenés következményeként száradási repedések alakulnak ki, amelyek sokszögletü (poligonális) rendszert képeznek a sík vagy közel sík térszíneken. Fehéres szürke színüket az oldatokból kiváló sók okozzák.

\section{Összefoglalás}

Az iszapvulkáni területen végzett felszínalaktani vizsgálatok eredményeit összefoglalva elmondható, hogy a legnagyobb méretű felszínformák az iszapvulkáni kúpok, amelyeknek a tetején kráterek alakultak ki. Ezekben, ill. az iszapfelszínbe mélyedő iszapmedencékben törnek elő a különböző fluidok a gázok nyomása következtében a felszín alatti iszapkamrákból. Az iszapvulkánok szakaszos működése, anyaga, a kifolyt sár mennyisége, sürüsége gyakran változik, és ezek befolyásolják a lefolyás típusát és irányát is. Mind a mikro-, mind a makroformák (iszapkúp, kráter, sárfolyás, monogenetikus iszapkúp, iszapmaar, iszaplyuk stb.) sok hasonló vonást mutatnak az igazi vulkáni területekkel, de jóval kisebbek azoknál, és nem a magmatikus folyamatok alakítják ki őket. A sárfolyások mentén sárhidak és alagutak ott alakulnak ki, ahol a híg sárfolyás tetején a sürü iszap kérget, redőket képez, összeáll és befedi a hígan folyó sár csatornáját. Ezek hasonlóképpen képződnek, mint a lávakéregbarlangok a valódi vulkáni területek pahoehoe típusú lávafolyásainál. Alagútszerü forma képződik akkor is, ha egy vályút viszkózusabb sárfolyás keresztezi, és úgy képez fedelet a vályú felett, hogy alatta a vályú nyitva marad vagy csak részlegesen zárul el, amit egy későbbi híg sárfolyás újból megnyit. $\mathrm{Az}$ iszapvulkáni területek lejtős peremvidékén, ahol a lefolyó sáros víz mélyebb árkokat vés a régi iszaptérszínbe, megfigyelhetők alagosodáshoz (szuffózió, piping) kapcsolódó 
formák is, víznyelők, barlangi méretü vízvezető járatok, sőt forrásbarlangok, amelyek jellemző mérete a dm-es nagyságrendtől a néhány m-es nagyságig terjed. A több éven keresztül végzett megfigyelések szerint azonban a felszínformák gyakran változnak, mivel a gázok feltörési helye és a kitörés típusa is változik.

\section{Köszönetnyilvánítás}

Ezúton szeretnék köszönetet mondani a Tempus Közalapítvány kuratóriumának a Stipendium ösztöndíjon keresztül nyújtott támogatásért, az Erasmus+ támogatásért és az ELTE Tehetség Pályázat támogatásért, amely segítséget nyújtott a terepi kutatásokhoz. Köszönettel tartozom a Bukaresti Egyetem Földrajz Karán dr. STRAT Daniela egyetemi docensnek a terepi munkákban és az egyetemközi szervezésben nyújtott támogatásért, valamint egyetemi kollégámnak, dr. Bíró TAMÁs tanársegédnek a valódi vulkáni és az iszapvulkáni formák összehasonlításában nyújtott segítségéért.

\section{Irodalom}

Andrășanu, A. 2010: Buzauland geopark. Steps in building a new geopark in Romania. - Scientific Annals - School of Geology, Aristotle University of Thessaloniki. Proceedings of the XIX CBGA Congress, Thessaloniki, Greece. Special volume 100. pp. 503-512.

BÁNYAI J. 1932: Udvarhely vármegye iszapforrásai. - EME Természettudományi Szakosztály közleményei. pp. 1-17.

Brustur, T. - Stănescu, I. - Macaleț, R. - Melinte-Dobrinescu, M. C.2015: The mud volcanoes from Berca: a significant geological patrimony site of the Buzău Land Geopark (Romania). - Geo-Eco-Marina 21. pp. 73-96.

CiocÂRdel, R. (1949). Regiunea petroliferă Berca-Beciu-Arbănaşi. - Comunicări de Geologie, Studii tehnico-economice A1. 32 p.

COBĂLCESCU, G. 1883: Studii geologice și paleontologice asupra unor terâmuri terțiare din unele părțiale României. - Stabilimentul Grafic Socecu \& Teclu, Bucuresti, 185 p.

Dimitrov, L. I. 2002: Mud volcanoes - the most important pathway for degassing deeply buried sediments. - Earth-Science Reviews 59. pp. 49-76. https://doi.org/10.1016/S0012-8252(02)00069-7

Etiope, G. - Baciu, C. - CAracausi, A. - Cosma, C. 2009: Gas flux to the atmosphere from mud volcanoes in Eastern Romania. - Terra Nova 16. 4. pp. 179-184. https://doi.org/10.1111/j.1365-3121.2004.00542.x Etiope, G. - NAKada, R. - TANaka, K. - Yoshida, N. 2011: Gas seepage from Tokamachi mud volcanoes, on shore Niigata Basin (Japan): origin, post-genetic alterations and $\mathrm{CH}_{4}-\mathrm{CO}_{2}$ fluxes. - Applied Geochemistry 26. pp. 348-359. https://doi.org/10.1016/j.apgeochem.2010.12.008

GADÁNYi P. 2008: Kéreg alatti bazaltláva barlangok. - Karszt és Barlang I-II. pp. 21- 33.

GÁL A. 2010: Mud volcanoes from the Eastern and central part of the Transylvanian Depression. Extended abstract of PhD thesis. - Babeş-Bolyai University Faculty of Geography. Kézirat. 163 p. 
Halliday, W. R. (szerk.) 1976: Proceedings of the International Symposium on Vulcanospeleology and its Extraterrestrial Applications. - Special Session of the 29th Annual Convention of the National Speleological Society. Washington. $85 \mathrm{p}$.

Halliday, W. 2006: Piping caves and badlands pseudokarst. - In: Gunn, J. (szerk.): Encyclopedia of caves and karst science. pp. 1260-1968.

Higgins, G. E. - SAunders, J. B. 1973: Mud volcanoes - their nature and origin: contribution to the geology and paleobiology of the Carribbean and adjacent areas. - Verhandlungen der Schweizerischen Naturforschenden Gesellschaft 84. pp. 101-152.

Kopf, A. J. 2002: Significance of mud volcanism. - Reviews of Geophysics 40. 2. pp. 2-52. https://doi. org/10.1029/2000RG000093

Mazzini, A. - Etiope, G. 2017: Mud volcanism: an updated review. - Earth-Science Reviews 168. pp. 81-112. https://doi.org/10.1016/j.earscirev.2017.03.001

Melinte-Dobrinescu, M. C. - Brustur, T. - Jipa, D. C. - Ion, G. - Macaleț, R. - Briceag, A. Rotaru, S. 2017: Geological investigations and mapping in the Buzău Land Geopark: state of the art. Geo-Eco-Marina, pp. 133-144.

Oтvos E. G. 1976: "Pseudokarst” and "pseudokarst terrains": problems of terminology. - Geological Society of America 87. 7. pp. 1021-1027. https://doi.org/10.1130/0016-7606(1976)87<1021:PAPTPO>2.0.CO;2

Parker, G. G. - Higgins, C. G. - Wood, W. W. 1990: Piping and pseudokarst in drylands. - In: Higgins, C. G. - Coates, D. R. (szerk.): Groundwater geomorphology. The role of subsurface water in earth-surface processes and landforms. Geological Society of America 252. pp. 77-110. https://doi.org/10.1130/ SPE252-p77

Stoica, M. - Andrășanu, A. - PAlcu, D. - Popa, R. G. 2017: The Miocene from Buzău area. A geological and geoconservation perspective. - The 11th Romanian Symposium on Palaeontology, Bucharest, September 25-30. 2017. Editura Universitații din Bucuresți. 43 p.

SzÉKely A. 1974: Az Etna vulkáni barlangjai. - Földrajzi Közlemények 98. 2. pp. 149-153.

Veress M. 2004: A karszt. - Szombathely. 382 p.

ZHU, T. X. - LuK, S. H. - CAI, Q. G. 2002: Tunnel erosion and sediment production in the hilly loess region, North China. - Journal of Hydrology 257. pp. 78-90. https://doi.org/10.1016/S0022-1694(01)00544-3 